\title{
Evaluation of a Commercial High-Protein Distiller's Dried Grain with Solubles (HP-DDGS) Product in the Diet of Juvenile Nile Tilapia (Oreochromis niloticus)
}

\author{
Blaine A. Suehs $\mathbb{D}$ and Delbert M. Gatlin III $\mathbb{D}$ \\ Department of Ecology and Conservation Biology, Texas A\&M University Wildlife, Fisheries, And Ecological Sciences Building, \\ 534 John Kimbrough Blvd., TAMUS, College Station, Texas 77843-2258, USA
}

Correspondence should be addressed to Blaine A. Suehs; bsuehs19@tamu.edu

Received 22 October 2021; Revised 17 December 2021; Accepted 4 January 2022; Published 31 January 2022

Academic Editor: Mansour Torfi Mozanzadeh

Copyright (C) 2022 Blaine A. Suehs and Delbert M. Gatlin III. This is an open access article distributed under the Creative Commons Attribution License, which permits unrestricted use, distribution, and reproduction in any medium, provided the original work is properly cited.

\begin{abstract}
A comparative feeding trial and digestibility determination were conducted to evaluate the nutritional value of a commercial, high-protein distiller's dried grains with solubles (HP-DDGS) ingredient in the diet of Nile tilapia (Oreochromis niloticus). For the feeding trial, six diets were formulated to contain $360 \mathrm{~g}$ total dietary protein $\mathrm{kg}^{-1}$ and were prepared with incremental levels of protein from the HP-DDGS $\left(0,75,150,225,300\right.$, and $375 \mathrm{~g}$ of dietary protein $\left.\mathrm{kg}^{-1}\right)$ replacing protein from fishmeal and soybean meal. Juvenile tilapia ( $10.4 \mathrm{~g} \pm 0.37$; average initial weight $\pm \mathrm{SD}$ ) were evenly distributed in 24 , 38 -L aquaria operated as a recirculating system and fed twice daily to apparent satiation throughout the 8-week trial. Nile tilapia exhibited no significant $(P>0.05)$ differences in weight gain, feed efficiency, condition indices, whole-body proximate composition, or innate immunological responses when fed any DDGS-supplemented diets compared to the control diet. Percent apparent digestibility coefficients (ADCs) of the DDGS product for organic matter, crude protein, and gross energy were $74.8 \%, 83 \%$, and $82.8 \%$, respectively. Availability values for all amino acids were $89 \%$ or greater. Thus, this high-protein DDGS was established as a readily digestible protein feedstuff suitable for replacing soybean meal and fishmeal at up to $375 \mathrm{~g}$ of total dietary protein $\mathrm{kg}^{-1}$ in a practical diet for Nile tilapia.
\end{abstract}

\section{Introduction}

Aquaculture has reached an all-time peak, supplying over 100 million of the world's 180 million tons of fish and aquatic products for human consumption as of 2018 , and aquacultural production is likely to continue expanding due to the demand of a growing human population and largely static harvest from capture fisheries [1-3]. The aquaculture sector is the fastest growing food production industry and has experienced an average growth rate of 5.8\% from 2000-2016 [3] furthering the economic strain placed on providing valuable feed resources to support intensive fish production (e.g., fishmeal and fish oil) [4].
To meet this challenge, the aquaculture industry has invested in evaluating fishmeal and fish oil replacements to alleviate unprecedented demand for those resources and allow for continued growth to meet the goal of providing cost-effective seafood for the global population. Promising alternatives to fishmeal and fish oil are diverse in nature but generally must contain adequate protein and/or lipid concentrations. These alternative ingredients range from terrestrial plant-based proteins and lipids (e.g., soybean meal and oil), single-cell protein and oil (e.g., phototrophic and heterotrophic algae), rendered terrestrial animal products (e.g., poultry by-product meal), seafood by-products (e.g., seafood processing wastes), and even insect meals (e.g., 
Black soldier fly larvae meal) [5]. Specifically, plant protein feedstuffs have been identified as crucial to the sustainability of aquaculture [6]. However, researchers are mindful of potential antinutritional factors in some plant feedstuffs that may negatively affect the health of cultured organisms, such as trypsin inhibitors in soybean meal [7] and gossypol concentrations in cottonseed meal [8].

Distiller's dried grain with solubles (DDGS) is a maizebased coproduct of ethanol production via fermentation which is accomplished by a combination of various enzymes and yeasts [9]. Historically, DDGS is produced during dry grind ethanol production through the steps of liquification, saccharification, fermentation, distillation (dry coproduct DDGS is produced), and dehydration [10]. Once the DDGS is harvested, reported variability in physical properties (e.g., color and texture) and moisture content of DDGS products are primarily based on variances in steam treatment and screw speed throughput $[11,12]$. The dry grind ethanol process creates an economically feasible and sustainable alternative protein feedstuff at approximately $10 \%$ the cost relative to commercial fishmeal and $45 \%$ to that of soybean meal [13]. When compared on a dry-matter, crude-protein (CP) basis, DDGS (USD0.12 $\mathrm{kg}^{-1} \mathrm{CP}$ ) is also substantially cheaper than fishmeal (USD0.58 kg-1 CP) and soybean meal (USD0.21 kg-1 CP) potentially reducing high costs associated with high-protein aquatic diets [13-15].

The nutrient content of traditional DDGS (approximately $306 \mathrm{~g} \mathrm{~kg}^{-1} \mathrm{CP}$ and $100 \mathrm{~g} \mathrm{~kg}^{-1}$ lipid [15]) is suitable for moderate levels of dietary inclusion for some fish species. However, the carbohydrate (CHO) concentration of the ingredient could be a potential factor limiting inclusion when formulating diets for carnivorous fish which typically have lower ability to digest soluble CHOs. Total $\mathrm{CHO}$ content in DDGS has been measured upwards of $500 \mathrm{~g} \mathrm{~kg}^{-1}$ of dry weight, with nonstarch $\mathrm{CHO}$ (i.e., nondigestible fiber) composing approximately $341-420 \mathrm{~g} \mathrm{~kg}^{-1}$ of dry weight [15, 16]. Thus, DDGS would appear to be more efficiently supplemented in the diet of species capable of metabolizing higher levels of soluble $\mathrm{CHO}$, such as Nile tilapia. Technological advancements have given rise to high-protein DDGS (HP-DDGS) created via further separation of indigestible fiber, as well as refinement of the dry grind process, thereby increasing crude protein concentration to $390-480 \mathrm{~g} \mathrm{~kg}^{-1}$ dry weight, but only moderately enhancing lysine and methionine concentrations $[9,17,18]$. Another obstacle inhibiting aggressive DDGS inclusion in diets of fish is its limited lysine and methionine concentrations (the most limiting amino acids in aquatic diets when replacing fishmeal) [19]. On average, lysine and methionine represent 10.0 and $6.0 \mathrm{~g} \mathrm{~kg}^{-1}$ dry weight of DDGS, respectively ( 36.0 and $22.0 \mathrm{~g} \mathrm{~kg}^{-1}$ CP) [20] compared to 52.9 and $20.2 \mathrm{~g} \mathrm{~kg}^{-1}$ dry weight $\left(\sim 83.0\right.$ and $32.0 \mathrm{~g} \mathrm{~kg}^{-1}$ of CP) in menhaden fishmeal [14]. Deficiencies in these indispensable amino acids may result in decreased metabolic function of the organism, including impairment of growth performance, development, and overall health [21]. Nonetheless, adequate growth of cultured species can be supported through supplementation of limiting amino acids, thereby increasing the potential inclusion of HP-DDGS or other alternative protein ingredients [14].
Despite relatively high amounts of nondigestible $\mathrm{CHO}$ and limiting lysine and methionine concentrations, DDGS (traditional and HP-DDGS) are promising plant-protein ingredients due to a lack of antinutritional factors which may be present in other plant feedstuffs $[6,22]$.

A new commercial HP-DDGS ingredient, ProCap Gold (Marquis Energy, Hennepin, IL, USA), has been developed that separates protein- and lipid-rich fermented corn and yeast fractions from nondigestible fiber fractions in the dry grind process (Cristobal et al., 2020). Coupled with an increase in analyzed crude protein concentration $\left(542.0 \mathrm{~g} \mathrm{~kg}^{-1}\right.$ dry weight) and lysine concentration (15.2 $\mathrm{g} \mathrm{kg}^{-1}$ dry weight) and decrease in nondigestible fiber $\left(65.6 \mathrm{~g} \mathrm{~kg}^{-1}\right)$, the digestibility of the HP-DDGS ingredient could potentially be enhanced, particularly in energy and organic matter, thus potentially improving growth of cultured fish and allowing greater dietary levels of inclusion. This abundant and patented HP-DDGS ingredient presents a desirable alternative to fishmeal and soybean meal, based on the increased protein and indispensable amino acid composition. With a global production of approximately 7 million tons in 2020 and expected to increase in the near future [3], Nile tilapia represents a model species in which ProCap Gold HP-DDGS is desirable to spare dietary fishmeal inclusion and lessen the global demand.

Therefore, an 8-week comparative feeding trial was conducted to evaluate growth performance, body condition indices, whole-body composition, and immunological responses of juvenile Nile tilapia fed increasing levels of ProCap Gold DDGS in place of soybean and fishmeal protein in practical diets. Subsequently, a digestibility trial was conducted to assess apparent digestibility coefficients (ADCs) of this new HP-DDGS, Procap Gold, ingredient for Nile tilapia.

\section{Methods}

\subsection{Feeding Trial}

2.1.1. Diets, Cultured Fish, and System. The comparative feeding trial was conducted at the Texas A\&M University (TAMU) Aquacultural Research and Teaching Facility (College Station, TX) using juvenile Nile tilapia. Initially, six practical isonitrogenous, isolipidic, and isoenergetic diets were formulated to contain $360 \mathrm{~g}$ crude protein (CP) $\mathrm{kg}^{-1}$, $65 \mathrm{~g}$ crude fat $\mathrm{kg}^{-1}$, and $\sim 2910 \mathrm{Kcal}$ gross energy (GE) $\mathrm{kg}^{-1}$ (Table 1). Nutrient proximate composition of the HP-DDGS experimental ingredient was also assessed to determine efficacy (Table 1). To further verify the viability of the HPDDGS ingredient, amino acid content of the experiment ingredient was evaluated (Table 2) by MassTrak AAA HPLC Program (Waters Corporation, Milford, MA). Dietary AA composition was also assessed to ensure homogeneity of the dietary treatments and integrity of the comparative feeding trial using identical methodology (Table 3). All dietary treatments satisfied established nutrient requirements of Nile tilapia [15].

Of the $360 \mathrm{~g} \mathrm{~kg}^{-1} \mathrm{CP}$ in the basal diet, soy-based protein (soybean meal and soy protein concentrate) contributed $306 \mathrm{~g} \mathrm{~kg}^{-1}$ with $36 \mathrm{~g} \mathrm{~kg}^{-1}$ of total protein from wheat flour 
TABLE 1: Formulation and proximate composition ( $\mathrm{g} \mathrm{kg}^{-1}$ dry diet weight) of the control diet and experimental diets containing graded levels of ProCap Gold HP-DDGS ingredient which were fed to Nile tilapia. Diet labels indicate total protein contributed by HP-DDGS in $\mathrm{g}$ kg ${ }^{-1}$.

\begin{tabular}{|c|c|c|c|c|c|c|}
\hline Ingredient & Control & ProCap 75 & ProCap 150 & ProCap 225 & ProCap 300 & ProCap 375 \\
\hline HP-DDGS $^{\mathrm{a}}(54 \%$ CP) & 0.0 & 49.0 & 98.0 & 147.0 & 196.0 & 244.5 \\
\hline Soy protein concentrate ${ }^{\mathrm{b}}$ & 76.0 & 76.0 & 76.0 & 76.0 & 76.0 & 76.0 \\
\hline Menhaden meal ${ }^{\mathrm{c}}$ & 29.0 & 26.0 & 23.0 & 20.0 & 17.5 & 14.5 \\
\hline Soybean meal ${ }^{\mathrm{d}}$ & 482.0 & 434.0 & 385.5 & 337.5 & 289.0 & 241.0 \\
\hline Wheat flour ${ }^{\mathrm{e}}$ & 198.0 & 198.0 & 198.0 & 198.0 & 198.0 & 198.0 \\
\hline Dextrinized corn starch ${ }^{f}$ & 60.0 & 60.0 & 60.0 & 60.0 & 60.0 & 60.0 \\
\hline Carboxylmethyl cellulose ${ }^{\mathrm{f}}$ & 20.0 & 20.0 & 20.0 & 20.0 & 20.0 & 20.0 \\
\hline Soybean oil & 48.5 & 39.0 & 29.5 & 19.5 & 10.0 & 0.5 \\
\hline Vitamin premix ${ }^{\mathrm{g}}$ & 30.0 & 30.0 & 30.0 & 30.0 & 30.0 & 30.0 \\
\hline Mineral premix ${ }^{\mathrm{g}}$ & 40.0 & 40.0 & 40.0 & 40.0 & 40.0 & 40.0 \\
\hline DL-methionine ${ }^{\mathrm{h}}$ & 5.0 & 5.0 & 5.0 & 5.0 & 5.0 & 5.0 \\
\hline Celufil $^{\mathrm{f}}$ & 11.5 & 23.0 & 35.0 & 47.0 & 58.5 & 70.5 \\
\hline \multicolumn{7}{|c|}{ Analyzed proximate composition of $\operatorname{diet}^{\mathrm{i}}$} \\
\hline Dry matter & 888.7 & 886.3 & 885.9 & 903.7 & 904.4 & 905.9 \\
\hline Crude protein & 370.0 & 368.2 & 371.1 & 373.2 & 371.8 & 372.0 \\
\hline Crude fat & 65.2 & 61.4 & 66.9 & 67.2 & 68.6 & 70.8 \\
\hline Ash & 76.1 & 73.9 & 71.7 & 69.9 & 67.2 & 64.8 \\
\hline Gross energy $\left(\mathrm{Kcal} \mathrm{kg}^{-1}\right)$ & 2913.3 & 2914.5 & 2914.6 & 2911.4 & 2913.3 & 2912.4 \\
\hline \multicolumn{7}{|c|}{ Analyzed proximate composition of ProCap Gold ingredient ${ }^{\mathrm{i}}$} \\
\hline Dry matter & 934.5 & & & & & \\
\hline Crude protein & 541.6 & & & & & \\
\hline Crude fat & 223.8 & & & & & \\
\hline$\sum$ saturated fatty acids & 29.6 & & & & & \\
\hline$\sum$ monounsaturated fatty acids & 69.2 & & & & & \\
\hline Epolyunsaturated fatty acids & 99.2 & & & & & \\
\hline$\sum \mathrm{n}-3$ fatty acids & 2.30 & & & & & \\
\hline$\sum \mathrm{n}-6$ fatty acids & 97.8 & & & & & \\
\hline Total carbohydrate $(\mathrm{CHO})$ & 137.7 & & & & & \\
\hline Crude fiber & 65.6 & & & & & \\
\hline Neutral detergent fiber (NDF) & 380.2 & & & & & \\
\hline Acid detergent fiber (ADF) & 140.2 & & & & & \\
\hline Ash & 31.4 & & & & & \\
\hline Organic matter & 968.6 & & & & & \\
\hline Gross energy $\left(\mathrm{Kcal} \mathrm{KJ}^{-1}\right)$ & 5758.0 & & & & & \\
\hline
\end{tabular}

${ }^{\mathrm{a}}$ Marquis Energy (ProCap Gold), Hennepin, IL, USA. ${ }^{\mathrm{b}}$ Solae LLC, St. Louis, MO, USA. ${ }^{\mathrm{c} O m e g a}$ Protein Corporation, Abbeville, LA, USA. ${ }^{\mathrm{d}}$ Producers Cooperative Association, Bryan, TX, USA. ${ }^{e}$ Rangen Inc., Angleton, TX, USA. ${ }^{\mathrm{f}}$ MP Biomedicals, Solon, OH, USA. ${ }^{\mathrm{g}}$ Same as in Moon and Gatlin III (1991).

${ }^{\mathrm{h}}$ Ajinomoto North America Inc., Itasca, IL, USA. ${ }^{\mathrm{i}}$ Means of three replicate analyses.

and the remaining $18 \mathrm{~g} \mathrm{~kg}^{-1}$ contributed by menhaden fishmeal. ProCap HP-DDGS was supplemented to the basal diet at five incremental levels replacing soybean meal and fishmeal such that the total protein contributed by HP-DDGS equaled $75,150,225,300$, or $375 \mathrm{~g} \mathrm{~kg}^{-1}$. As HP-DDGS was supplemented to the diet, inclusion ratio of soybean products and fishmeal progressively and equally decreased until contributing 350 and $25 \mathrm{~g} \mathrm{~kg}^{-1}$ of dietary protein, respectively, in the diet with the highest level of HP-DDGS. Identification of experimental treatments is based on a measure of total protein contribution.
All diets were produced on site at the Texas A\&M Aquacultural Research and Teaching Facility. Accurately weighed dry ingredients were homogenized by industrial grade $\mathrm{V}$ mixer for 30 minutes prior to oil and water addition and mixing followed by pelleting into $3 \mathrm{~mm}$ strands, as previously described by Yamamoto et al. [23]. Proximate composition of the dried diets was measured in accordance with Association of Official Analytical Chemists (AOAC) [24] methods. Briefly, crude protein was measured by a LECO (St. Joseph, MI, USA) 828 Nitrogen and Protein Determinator, crude lipid content was determined by chloroform- 
TABle 2: Amino acid (AA) composition of ProCap Gold HPDDGS experimental ingredient ( $\mathrm{g}$ of $\mathrm{AA} \mathrm{kg}^{-1}$ dry diet).

\begin{tabular}{lc}
\hline g of AA kg ${ }^{-1}$ dry diet & ProCap Gold \\
\hline Indispensable AA & \\
Arg & 22.9 \\
His & 12.1 \\
Ile & 15.9 \\
Leu & 50.8 \\
Lys & 15.2 \\
Met & 8.40 \\
Phe & 24.8 \\
Thr & 20.3 \\
Val & 25.0 \\
Dispensable AA & \\
Ala & 31.4 \\
Asn/Asp & 31.3 \\
Cys & 7.40 \\
Gln/Glu & 64.8 \\
Gly & 20.1 \\
Pro & 34.1 \\
Ser & 23.6 \\
Tyr & 20.0 \\
\hline
\end{tabular}

methanol extraction (Folch et al., 1957), and ash/organic matter content was determined by combustion in a furnace at $650^{\circ} \mathrm{C}$ for a 3.5 -hour duration.

A total of 360 juvenile Nile tilapia were acquired from the stock maintained at the Aquacultural Research and Teaching Facility. Fish were evenly distributed into 24, 38$\mathrm{L}$ aquaria operating as a recirculating aquaculture system (RAS), complete with settling chamber, biological filter, sand filter, and UV sterilizer. Photoperiod was regulated with fluorescent lights controlled with a timer to provide a $12: 12 \mathrm{~h}$ light: dark cycle. The 15 fish per aquaria were conditioned and quarantined in the experimental system for 1 week prior to initiation of the trial during which time they were fed the formulated basal diet. After the conditioning period, quadruplicate groups of Nile tilapia $(10.4 \mathrm{~g} \pm 0.37$; average initial weight \pm SD) were then randomly assigned to each experimental diet and fed to apparent satiation for 8 weeks based on a set percentage of body weight per aquaria. Growth rate was monitored weekly by group weighing all fish in each aquarium, and the feeding ration, initially set at $4.0 \%$ body weight, was adjusted downward on a weekly basis to maintain a level close to apparent satiation without overfeeding. Water quality was consistently maintained at acceptable levels and measured twice weekly and reported as follows (average $\pm \mathrm{SD}$ ): temperature $-27.8 \pm 0.5^{\circ} \mathrm{C}$, dissolved oxygen $-5.7 \pm 0.6 \mathrm{mg} \mathrm{L}^{-1}$, total ammonia nitrogen$0.07 \pm 0.04 \mathrm{mg} \mathrm{L}^{-1}$, total nitrite nitrogen $-0.04 \pm 0.03 \mathrm{mg} \mathrm{L}^{-1}$, $\mathrm{pH}-7.6 \pm 0.1$, and salinity $-1.2 \pm 0.4 \mathrm{gL}^{-1}$.

2.1.2. Sampling Procedures and Data Collection. An initial sample of 20 juvenile Nile tilapia was collected before the start of the feeding trial and stored at $-20^{\circ} \mathrm{C}$ for analysis of
TABle 3: Amino acid (AA) composition of experimental diets supplemented with ProCap Gold HP-DDGS ingredient ( $g$ of AA $\mathrm{kg}^{-1}$ dry diet).

\begin{tabular}{lcccccc}
\hline g of AA kg dry diet & Control & 75 & 150 & 225 & 300 & 375 \\
\hline Indispensable AA & & & & & & \\
Arg & 26.6 & 28.1 & 25.0 & 26.3 & 24.9 & 23.8 \\
His & 9.40 & 9.90 & 9.20 & 10.2 & 9.90 & 9.40 \\
Ile & 17.3 & 18.0 & 16.6 & 17.5 & 17.1 & 17.0 \\
Leu & 27.0 & 29.7 & 27.9 & 30.3 & 31.1 & 32.3 \\
Lys & 18.6 & 19.6 & 16.7 & 16.3 & 16.1 & 16.3 \\
Met & 7.20 & 6.50 & 7.70 & 9.00 & 8.70 & 8.80 \\
Phe & 19.1 & 19.9 & 18.8 & 21.0 & 20.2 & 19.0 \\
Thr & 15.9 & 17.5 & 15.5 & 16.4 & 16.2 & 16.2 \\
Val & 17.4 & 19. & 17.6 & 18.8 & 19.0 & 19.4 \\
Dispensable AA & & & & & & \\
Ala & 17.8 & 20.1 & 18.8 & 20.3 & 21.3 & 22.6 \\
Asn/Asp & 30.8 & 32.7 & 28.9 & 28.8 & 28.4 & 28.3 \\
Gln/Glu & 78.6 & 85.0 & 76.3 & 77.7 & 78.0 & 79.0 \\
Gly & 17.7 & 18.5 & 17.1 & 18.6 & 18.0 & 17.5 \\
Pro & 22.6 & 24.2 & 23.0 & 25.0 & 25.4 & 26.1 \\
Ser & 39.1 & 42.1 & 38.3 & 40.6 & 40.0 & 39.5 \\
Tyr & 11.7 & 12.2 & 11.7 & 13.1 & 12.2 & 11.5 \\
\hline
\end{tabular}

whole-body proximate composition at a later date. At the end of the 8-week feeding trial, aquaria weight was measured for production performance parameters, including percentage weight gain ([g final weight - initial weight/g initial weight] $\times 100$ ), feed efficiency (g dry feed offered/g weight gain), protein conversion efficiency ([(final body wt. $(\mathrm{g}) \times$ final body protein $(\%)$ ) - (initial body wt. $(\mathrm{g}) \times$ initial body protein $(\%))] /$ protein intake $(\mathrm{g})] \times 100)$, and survival ([\#surviving fish/initial stocking density $] \times 100)$. After determination of total biomass weight per aquarium, six fish per aquarium were randomly collected for whole-body proximate composition analysis and determination of condition indices based on protocols described by Rossi Jr et al. [25]. Briefly, three of the six fish per aquarium were euthanized by an overdose $\left(300 \mathrm{mg} \mathrm{L}^{-1}\right)$ of tricaine methanesulfonate (MS-222; Western Chemical, Ferndale, Washington) and stored at $-20^{\circ} \mathrm{C}$ for whole-body proximate composition analyses, along with the initial sample of fish, according to [24] methods which were identical to procedures described for diet proximate composition analyses. The three fish per aquarium were combined and homogenized as composite samples of whole-body tissue.

The three remaining fish per aquarium were anaesthetized using tricaine methanesulfonate $\left(100 \mathrm{mg} \mathrm{L}^{-1}\right)$ prior to blood sample collection via heparinized syringes through the caudal peduncle vasculature and then euthanized via a higher dose $\left(300 \mathrm{mg} \mathrm{L}^{-1}\right)$ of tricaine methanesulfonate. Fish were bled prior to weighing to accurately measure innate immune responses as described below. Collected wholeblood samples were kept refrigerated at $4^{\circ} \mathrm{C}$ prior to centrifugation. After bleeding, fish were weighed and ventrally dissected for removal of intraperitoneal fat and liver for 
computation of condition indices including intraperitoneal fat (IPF) ratio $(100 \times \mathrm{g}$ IPF weight/g body weight $)$ and hepatosomatic index (HSI) $(100 \times \mathrm{g}$ liver weight/g body weight $)$, as described by Castillo et al. [26]. Those three fish per aquarium also were filleted for determination of muscle ratio expressed as a percent of body weight $(100 \times \mathrm{g}$ fillet weight/g body weight).

Collected whole-blood samples were aliquoted and stored separately in $2 \mathrm{ml}$ Eppindorf tubes and then incubated with $2 \mathrm{mg}$ of nitroblue tetrazolium (NBT, cat\# 97061-412, VWR International) per $\mathrm{mL}^{-1}$ in a 96-well microplate for oxidative radical production analysis, first described by Siwicki et al. [27] with modifications according to Yamamoto et al. [28]. Remaining blood samples were centrifuged at 3,000 $\times \mathrm{g}$ for a 15 -minute duration for plasma separation and stored at $-80^{\circ} \mathrm{C}$ for plasma immunological assays, including total protein, immunoglobulins, lysozyme activity, and antiprotease activity. Plasma total protein, immunoglobulin, and lysozyme activity was determined as described by Yamamoto et al. [28]. Plasma antiprotease activity measurement was performed according to the procedures of Ellis [29].

\subsection{Digestibility Trial}

2.2.1. Diets, Cultured Fish, and System. A nutritionally complete commercial diet for omnivorous fish $\left(\sim 360 \mathrm{~g} \mathrm{CP} \mathrm{kg}^{-1}\right.$, $55 \mathrm{~g}$ crude lipid $\mathrm{kg}^{-1}$, and $4163 \mathrm{Kcal} \mathrm{kg}^{-1}$ dry-matter basis) was ground through a $1 \mathrm{~mm}$ hammermill screen and combined with $20 \mathrm{~g} \mathrm{~kg}^{-1}$ carboxymethyl cellulose (CMC) (MP Biomedicals, Solon, $\mathrm{OH}, \mathrm{USA}$ ) and $1 \mathrm{~g} \mathrm{~kg}^{-1}$ yttrium oxide $\left(\mathrm{Y}_{2} \mathrm{O}_{3}\right.$, Sigma Aldrich Co. $)$ and then pelleted by passing through a meat grinder and $5 \mathrm{~mm}$ diet to serve as the reference diet. The experimental diet $\left(\sim 10 \mathrm{~g} \mathrm{CP} \mathrm{kg}^{-1}, 100 \mathrm{~g}\right.$ crude fat $\mathrm{kg}^{-1}$, and $4835 \mathrm{Kcal} \mathrm{kg}^{-1}$ dry-matter basis) consisting of $730 \mathrm{~g}$ of the ground commercial reference diet $\mathrm{kg}^{-1}, 250 \mathrm{~g}$ of the ProCap DDGS ingredient $\mathrm{kg}^{-1}, 20 \mathrm{~g} \mathrm{CMC} \mathrm{kg}^{-1}$, and $1 \mathrm{~g}$ yttrium oxide $\mathrm{kg}^{-1}$ was homogenized in a food mixer and pelleted similar to the reference diet. A total of 120 advanced stage Nile tilapia (ranging from 75 to $150 \mathrm{~g}$ ), obtained from the stock maintained at the TAMU Aquacultural Research and Teaching Facility, were evenly distributed into four, 1,200-L round tanks operating as a RAS, complete with settling chamber, biological filter, sand filter, and UV sterilizer. Each tank was randomly assigned a digestibility diet, allowing for two replicates of each dietary treatment. Fish were fed to apparent satiation the assigned diets for a duration of 1-week prior to sample collections. After the initial fecal collection was completed, fish in all four tanks were then reconditioned for a period of 1 week using the commercial diet. Thereafter, each experimental digestibility diet was reassigned randomly to two tanks for an additional fecal collection. Thus, four independent replicate samples were obtained for the reference and experimental diets.

\subsubsection{Fecal Collection and Calculated Apparent Digestibility} Coefficients. Feces from each tank were collected on two separate and independent occasions and considered replicate samples, as previously described. Prior to collection, tanks were cleaned and siphoned with a partial water exchange to prevent contamination of the samples. For each collection, fish were fed to apparent satiation in the morning, and feces was physically harvested by netting every 30 minutes for a 6-hour duration [30]. Composite samples of feces from each tank were dried at $60^{\circ} \mathrm{C}$ overnight and finely ground with mortar and pestle. Then, fecal and diet samples were analyzed for proximate composition as previously described. In addition, samples were digested and analyzed for amino acid composition as previously described [26] and gross energy content by adiabatic calorimetry. Apparent digestibility coefficient (ADC) values of the reference and experimental diets were calculated according to the equation described by Amirkolaie et al. [31] and NRC [15] which also allowed calculation of the ADC values of the ProCap ingredient; $\operatorname{diet} \mathrm{ADC}$ of nutrient $=\left(1-\left[\mathrm{yttirum}_{\text {diet }} / \mathrm{yttrium}_{\text {feces }} \times\right.\right.$ Nutr $\left._{\text {feces }} / \mathrm{Nutr}_{\text {diet }}\right] \times 100$; ingredient ADC of nutrient $=(\mathrm{AD}$ $\mathrm{C}_{\text {exp.diet }}+\left[\left(\mathrm{ADC}_{\text {exp.diet }}-\mathrm{ADC}_{\text {reference diet }}\right) \times(0.75 \times\right.$ Nutrient Comp. $\left.\%_{\text {ref.diet }}\right) /\left(0.25 \times\right.$ Nutrient Comp. $\left.\left.\%_{\text {exp.ingredient }}\right)\right] \times 100$.

2.3. Statistical Analysis. Growth performance, condition indices, whole-body proximate composition, and immunological assays of Nile tilapia fed graded levels of HP-DDGS were evaluated by linear and quadratic regression using the JMP Pro 15 software (SAS Institute Cary, NC). The lesser $P$ value was used to determine best fit of the model for significance determination. Homogeneity of variances was assessed by the Brown-Forsythe test, while data normality was assessed by the Shapiro-Wilk test. ADC values of the digestibility diets were assessed by one-way analysis of variance (ANOVA) using the JMP Pro 15 software. If significance $(P<0.05)$ was detected, data were subjected to Tukey's honestly significant difference. Significance was set at $\alpha=0.05$ for all statistical analyses.

\section{Results}

\subsection{Feeding Trial}

3.1.1. Growth Performance and Condition Indices. Juvenile Nile tilapia did not exhibit any significant $(P>0.05)$ differences in measured parameters of growth performance, including percentage weight gain, feed efficiency (FE), protein conversion efficiency (PCE), fillet yield, or survival in response to increasing levels of HP-DDGS in the diet (Table 4). Additionally, no significant $(P>0.05)$ differences were identified for evaluated condition indices (HSI, IPF ratio, and muscle yield) as these parameters did not exhibit significance in either linear or quadratic regression models (Table 4).

3.1.2. Whole-Body Proximate Composition. Juvenile Nile tilapia fed diets containing from 0 up to $375 \mathrm{~g}$ of protein $\mathrm{kg}^{-1}$ from HP-DDGS were not significantly $(P>0.05)$ different in dry matter, crude protein, crude fat, or ash concentrations in whole-body tissues (Table 5), when evaluated as a linear or quadratic regression model. However, whole-body fat composition of tilapia fed the diet in which HP-DDGS 
TABLE 4: Production performance of juvenile Nile tilapia fed diets supplemented with graded levels of HP-DDGS for 8 weeks.

\begin{tabular}{|c|c|c|c|c|c|c|c|c|c|}
\hline & Initial weight (g) & Final weight (g) & $\begin{array}{l}\text { Weight } \\
\text { gain }^{\mathrm{a}}(\%)\end{array}$ & $\mathrm{FE}^{\mathrm{b}}$ & $\operatorname{PCE}(\%)^{c}$ & $\begin{array}{c}\text { Muscle } \\
\text { ratio }(\%)^{\mathrm{d}}\end{array}$ & $\operatorname{HSI}^{\mathrm{e}}(\%)$ & $\operatorname{IPF}^{\mathrm{f}}(\%)$ & Survival $^{g}(\%)$ \\
\hline Control & 10.3 & 49.9 & 383 & 0.85 & 44.2 & 27.7 & 3.09 & 1.10 & 100 \\
\hline ProCap 75 & 11.3 & 47.6 & 321 & 0.79 & 40.0 & 27.3 & 2.73 & 1.33 & 97.8 \\
\hline ProCap 150 & 10.3 & 46.8 & 353 & 0.82 & 42.4 & 28.5 & 3.26 & 0.99 & 91.1 \\
\hline ProCap 225 & 10.7 & 50.4 & 376 & 0.87 & 43.4 & 26.1 & 2.92 & 1.13 & 100 \\
\hline ProCap 300 & 10.5 & 47.4 & 354 & 0.81 & 40.1 & 26.7 & 3.30 & 0.94 & 88.9 \\
\hline ProCap 375 & 10.5 & 48.6 & 364 & 0.83 & 42.5 & 26.7 & 3.32 & 1.40 & 95.6 \\
\hline PSE & 0.34 & 2.32 & 28.33 & 0.04 & 0.025 & 0.011 & 0.002 & 0.003 & 0.036 \\
\hline \multicolumn{10}{|l|}{ Linear } \\
\hline $\operatorname{Pr}>F$ & 0.68 & 0.87 & 0.85 & 0.94 & 0.73 & 0.30 & 0.14 & 0.53 & 0.24 \\
\hline$R^{2}$ & 0.011 & 0.002 & 0.022 & 0.000 & 0.008 & 0.06 & 0.12 & 0.02 & 0.08 \\
\hline \multicolumn{10}{|l|}{ Quadratic } \\
\hline $\operatorname{Pr}>F$ & 0.81 & 0.91 & 0.89 & 0.988 & 0.85 & 0.59 & 0.27 & 0.54 & 0.39 \\
\hline$R^{2}$ & 0.028 & 0.013 & 0.001 & 0.002 & 0.02 & 0.067 & 0.157 & 0.079 & 0.117 \\
\hline
\end{tabular}

Abbreviations: FE: feed efficiency; PCE: protein conversion efficiency; HSI: hepatosomatic index; IPF: intraperitoneal fat ratio; PSE: pooled standard error;

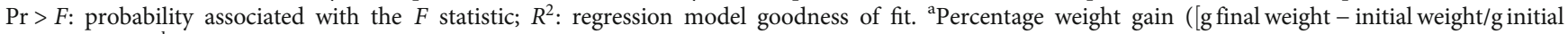
weight $] \times 100)$. ${ }^{b}$ Feed efficiency $(\mathrm{FE})\left(\mathrm{g}\right.$ dry feed offered/g weight gain). ${ }^{\mathrm{c}}$ Protein conversion efficiency $(\mathrm{PCE})([($ final body wt. $(\mathrm{g}) \times$ final body protein $(\%))-$ (initial body wt. $(\mathrm{g}) \times$ initial body protein $(\%))] /$ protein intake $(\mathrm{g})] \times 100)$. ${ }^{\mathrm{d}}$ Muscle ratio $\left(100 \times \mathrm{g}\right.$ fillet weight/g body weight). ${ }^{\mathrm{e}} \mathrm{Hepatosomatic}$ index $(\mathrm{HSI})$ $\left(100 \times\right.$ g liver weight/g body weight). ${ }^{\mathrm{f}}$ Intraperitoneal fat (IPF) ratio (100 $\times \mathrm{g}$ IPF weight/g body weight). ${ }^{\mathrm{g}}$ Survival (\%) (\#surviving fish/initial stocking density) $\times 100$.

provided $375 \mathrm{~g}$ of protein $\mathrm{kg}^{-1}$ was numerically larger $\left(82.9 \mathrm{~g} \mathrm{~kg}^{-1}\right)$ than all other experimental groups.

3.1.3. Immunological Assays. All measured immunological responses of Nile tilapia were not significantly $(P>0.05)$ affected by increasing levels of HP-DDGS inclusion based on linear or quadratic regression models (Table 6).

\subsection{Digestibility Trial}

3.2.1. Diet and Ingredient Apparent Digestibility Coefficients. Advanced stage Nile tilapia fed the experimental diet composed of $250 \mathrm{~g} \mathrm{~kg}^{-1}$ of the HP-DDGS ingredient exhibited no significant $(P>0.05)$ differences in all ADC values compared to the commercial reference diet (Table 7). Crude lipid ADC values were exceptionally low, indicating a potential limitation of the fecal collection method used in the current study, and therefore were excluded from results.

The HP-DDGS ingredient was readily digested by advanced stage Nile tilapia (Table 8 ). The ADCs for crude protein and digestible energy were high (83.1 and $82.8 \%$, respectively), with marginally decreased crude lipid and organic matter ADC values (72.5 and $74.8 \%$, respectively). Individual amino acid ADC values also were consistently high (Table 8).

\section{Discussion}

Traditional DDGS and HP-DDGS have been studied alternative protein ingredients in the diets of many aquacultured species with various degrees of success. Prior studies have evaluated the efficacy of dietary supplementation of both types of ingredients in the diets of freshwater omnivorous species such as Nile tilapia $[32,33]$ and channel catfish (Ictalurus punctatus) [19], as well as strictly carnivorous freshwater species, such as the hybrid striped bass (Morone chrysops $X M$. saxitilis) [34] and rainbow trout (Oncorhynchus mykiss) [35]. Successful supplementation of HP-DDGS products up to $50 \%$ of diet in place of soybean meal for omnivorous and carnivorous fish species attest to the potential use of this alternative protein feedstuff in diet formulations of various aquatic species [34, 36, 37]. While published literature often misconstrues traditional and HPDDGS, it is understood that HP-DDGS (a total dietary fiber reduced ingredient) is more desirable when replacing fish-derived protein feedstuffs due to its higher protein content and more readily digested nutrients.

The present study observed no apparent effect of ProCap Gold HP-DDGS supplementation up to $375 \mathrm{~g}$ of total protein $\mathrm{kg}^{-1}$ (244.5 $\mathrm{g}$ of formulated diet dry weight $\mathrm{kg}^{-1}$ ) on any growth performance parameters, condition indices, or whole-body proximate composition of juvenile Nile tilapia. It appears that ProCap Gold can replace soybean meal and fishmeal to comprise the majority of CP in a low-fishmeal diet. These results are mirrored by findings from numerous studies evaluating HP-DDGS and traditional DDGS supplementation in the diet of Nile tilapia. Coyle et al. [32] found that DDGS inclusion at $300 \mathrm{~g}$ dry weight $\mathrm{kg}^{-1}$ in combination with meat and bone meal $\left(260 \mathrm{~g} \mathrm{~kg}^{-1}\right)$ and fishmeal $\left(80 \mathrm{~g} \mathrm{~kg}^{-}\right.$ $\left.{ }^{1}\right)$ protein produced similar growth responses compared to a control diet containing soybean meal and fishmeal at 
TABle 5: Proximate composition of the whole-body tissues $\left(\mathrm{g} \mathrm{kg}^{-1}\right.$ wet basis) of Nile tilapia after 8 weeks of feeding the experimental diets $^{\mathrm{a}}$.

\begin{tabular}{lcccc}
\hline & Dry matter & Crude protein & Crude fat & Ash \\
\hline Control & 290.7 & 174.6 & 73.9 & 37.5 \\
ProCap 75 & 272.3 & 168.3 & 65.0 & 37.1 \\
ProCap 150 & 291.0 & 174.4 & 73.8 & 36.8 \\
ProCap 225 & 291.7 & 171.8 & 77.5 & 38.9 \\
ProCap 300 & 286.3 & 172.2 & 70.3 & 39.4 \\
ProCap 375 & 301.3 & 174.2 & 82.9 & 39.1 \\
& & & & \\
PSE & 0.007 & 0.002 & 0.004 & 0.002
\end{tabular}

$\begin{array}{lcccc}\text { Linear } & & & & \\ \operatorname{Pr}>F & 0.13 & 0.72 & 0.10 & 0.16 \\ R^{2} & 0.14 & 0.008 & 0.16 & 0.11\end{array}$

Quadratic

\begin{tabular}{lllll}
$\operatorname{Pr}>F$ & 0.19 & 0.65 & 0.15 & 0.38 \\
$R^{2}$ & 0.19 & 0.05 & 0.22 & 0.12 \\
\hline
\end{tabular}

Abbreviations: PSE: pooled standard error; $\operatorname{Pr}>F$ : probability associated with the $F$ statistic; $R^{2}$ : regression model goodness of fit. ${ }^{a}$ Data represent means of triplicate groups $(n=3)$.

$410 \mathrm{~g} \mathrm{~kg}^{-1}$ and $120 \mathrm{~g} \mathrm{~kg}^{-1}$, respectively. Another experimental diet in that study was composed of $300 \mathrm{~g}^{\mathrm{DDGS}} \mathrm{kg}^{-1}$ and $460 \mathrm{~g}$ soybean meal $\mathrm{kg}^{-1}$ but resulted in significantly $(P<0.05)$ reduced performance in all measured parameters [32]. Similarly, Herath et al. [37] observed no significant $(P>0.05)$ differences in mean weight gain, specific growth rate, feed conversion ratio, protein efficiency ratio, and survival of tilapia when HP-DDGS were included in diets devoid of fishmeal at 524 and $332 \mathrm{~g}$ of dry weight $\mathrm{kg}^{-1}$, respectively, in combination with soybean meal and poultry by-product meal when compared to a practical reference diet $\left(343 \mathrm{~g} \mathrm{CP} \mathrm{kg}^{-1}\right)$. The current study and literature provide evidence of the capacity of HP-DDGS ingredients to provide the majority of $\mathrm{CP}$ in diets for Nile tilapia.

Lysine and methionine are essential amino acids that support key metabolic functions of fish, such as protein formation and energy production $[38,39]$. As indicated earlier, lysine and methionine are typically the two most limiting amino acids in diets when replacing fishmeal [19]. Thus, lysine and methionine normally may need to be supplemented in formulated diets composed of high amounts of DDGS due to lower concentrations of those amino acids. Supplementation of lysine in diets with high inclusion of DDGS for Nile tilapia has been reported to range from approximately 2.0 to $6.0 \mathrm{~g}$ of dry diet weight $\mathrm{kg}^{-1}$ in published studies [33, 37, 40-42]. However, lysine composition of the HP-DDGS experimental ingredient used in the current study was analyzed at $15.2 \mathrm{~g} \mathrm{~kg}^{-1}$ dry weight $\left(42.2 \mathrm{~g} \mathrm{~kg}^{-}\right.$ ${ }^{1}$ of protein), significantly higher than traditional DDGS and HP-DDGS (10.1 and $13.4 \mathrm{~g} \mathrm{~kg}^{-1}$ by weight and 33 and $34.4 \mathrm{~g} \mathrm{~kg}^{-1}$ of protein, respectively) [15]. Therefore, lysine supplementation was not necessary to meet the requirement of Nile tilapia in the current study, thus allowing increased HP-DDGS supplementation. Methionine is a limiting sulfur amino acid that is present abundantly in menhaden fishmeal $\left(20.2 \mathrm{~g} \mathrm{~kg}^{-1}\right)$ compared to dehulled soybean meal $\left(6.40 \mathrm{~g} \mathrm{~kg}^{-1}\right)$ [14]. As a result, methionine supplementation of alternative protein aquatic diets is generally understood. The HP-DDGS ingredient used in the current study contained $\sim 8.40 \mathrm{~g} \mathrm{~kg}^{-1}$ of methionine, noticeably higher than dehulled soybean meal. Similar to lysine, excessive methionine supplementation in the present study was not necessary to meet the nutritional requirements of Nile tilapia.

Fish possess a highly evolved innate immune response, led by macrophages, leukocytes, and granulocytes [43]. Therefore, innate immune responses of whole-blood, plasma, and head-kidney-derived macrophages are consistently used for evaluation of immune capabilities of fish fed alternative ingredients. Once again, the current study observed no significant $(P>0.05)$ differences in measured innate immune response parameters. Similar to growth responses, this is consistent with literature that evaluated DDGS supplementation in Nile tilapia. While organismal variation in immune responses is evident between various trials, relative innate immune response parameters can be evaluated with confidence. Nile tilapia fed a diet supplemented with $400 \mathrm{~g}$ DDGS $\mathrm{kg}^{-1}$ exhibited no significant $(P>0.05)$ differences in white blood cell count, serum protein, or lysozyme activity compared to fish fed a practical control diet [41]. Lim et al. [41] also observed no significant differences in a disease challenge to test adaptive immune responses of these tilapias when exposed to Streptococcus iniae. Coupled with plasma/serum innate immune responses, whole-blood respiratory burst analysis also showed no significant $(P>0.05)$ differences in adult Nile tilapia [44]. Indirect analysis of immune function using circulating plasma cortisol revealed no apparent negative effects during acute stress challenge by short-term air exposure or confinement of Nile tilapia fed diets with up to $30 \%$ dry weight inclusion of DDGS [45]. Although the immunological effects of traditional DDGS are well documented, published knowledge of HP-DDGS on innate immune responses is somewhat lacking for Nile tilapia.

Conflicting reports of overstimulation, enhancement, or no effects on immune responses of fish fed high dietary levels of DDGS have led to contradictory conclusions on the effects of DDGS supplementation on immune function and health of various cultured species [34, 36, 40, 41, 46]. Specifically, hybrid striped bass fed experimental diets containing high protein ethanol yeast, an ingredient similar to HP-DDGS, exhibited abnormally elevated circulating peripheral cortisol levels in unstressed fish indicating immuno-overstimulation [34]. Conversely, Goda et al. [36] found that HP-DDGS improved overall immune function in European sea bass. Furthermore, differences observed could be resultant of physiological differences of fish between separate trials as well as discrepancies of the DDGS ingredient used (i.e., differences in production techniques or inconsistencies of the ingredient name (HP-DDGS and DDGS) in literature). HP-DDGS is composed of a high level 
TABle 6: Immunological responses of juvenile Nile Tilapia fed diets supplemented with graded levels of ProCap for 8 weeks ${ }^{\mathrm{a}}$.

\begin{tabular}{|c|c|c|c|c|c|c|c|}
\hline & $\begin{array}{c}\text { Blood neutrophil } \\
\text { oxidative radical } \\
\text { production } \\
\text { (Abs at } 545 \mathrm{~nm} \text { ) }\end{array}$ & $\begin{array}{c}\text { Intracellular } \\
\text { superoxide anion } \\
\text { production } \\
\text { (Abs at } 620 \mathrm{~nm}) \\
\end{array}$ & $\begin{array}{c}\text { Extracellular } \\
\text { superoxide anion } \\
\text { production } \\
\left(\mathrm{O}_{2}^{-} \text {nmol/well }\right) \\
\end{array}$ & $\begin{array}{c}\text { Plasma } \\
\text { lysozyme } \\
\text { activity } \\
\text { (units } / \mathrm{mL} \text { ) } \\
\end{array}$ & $\begin{array}{c}\text { Plasma } \\
\text { total } \\
\text { protein } \\
(\mathrm{mg} / \mathrm{mL}) \\
\end{array}$ & $\begin{array}{c}\text { Plasma total } \\
\text { immunoglobulins } \\
(\mathrm{mg} / \mathrm{mL})\end{array}$ & $\begin{array}{c}\text { Plasma } \\
\text { antiprotease } \\
\text { activity (\%) }\end{array}$ \\
\hline Control & 0.649 & 0.163 & 0.381 & 483.3 & 36.4 & 5.01 & 81.1 \\
\hline ProCap 75 & 0.581 & 0.133 & 0.308 & 505.6 & 36.3 & 5.22 & 80.8 \\
\hline ProCap 150 & 0.647 & 0.313 & 0.914 & 433.3 & 33.9 & 4.10 & 81.8 \\
\hline ProCap 225 & 0.499 & 0.150 & 0.757 & 444.5 & 36.2 & 4.47 & 79.7 \\
\hline ProCap 300 & 0.522 & 0.165 & 0.665 & 444.5 & 36.7 & 5.72 & 81.0 \\
\hline ProCap 375 & 0.601 & 0.155 & 0.465 & 416.6 & 33.7 & 3.65 & 81.9 \\
\hline PSE & 0.047 & 0.077 & 0.408 & 65.03 & 1.09 & 1.42 & 0.915 \\
\hline \multicolumn{8}{|l|}{ Linear } \\
\hline $\operatorname{Pr}>F$ & 0.20 & 0.86 & 0.68 & 0.31 & 0.33 & 0.65 & 0.70 \\
\hline$R^{2}$ & 0.099 & 0.002 & 0.011 & 0.065 & 0.060 & 0.013 & 0.009 \\
\hline \multicolumn{8}{|l|}{ Quadratic } \\
\hline $\operatorname{Pr}>F$ & 0.22 & 0.72 & 0.57 & 0.60 & 0.61 & 0.90 & 0.64 \\
\hline$R^{2}$ & 0.182 & 0.042 & 0.073 & 0.065 & 0.064 & 0.014 & 0.058 \\
\hline
\end{tabular}

Abbreviations: Abs: absorbance; PSE: pooled standard error; $\operatorname{Pr}>F$ : probability associated with the $F$ statistic; $R^{2}$ : regression model goodness of fit. ${ }^{a} D a t a$ represent means of triplicate groups $(n=3)$.

TABle 7: Percent apparent digestibility coefficients (ADCs) of reference and experimental diets obtained with Nile tilapia ${ }^{a}$. The experimental digestibility diet was formulated on a $75: 25$ ratio of the reference diet to ProCap ingredient.

\begin{tabular}{lccc}
\hline Diet & Organic matter & Crude protein & Gross energy \\
\hline Reference & 61.3 & 70.8 & 68.5 \\
Experimental & 61.1 & 74.9 & 73.1 \\
& & & \\
PSE $^{\mathrm{b}}$ & 4.28 & 1.29 & 3.03
\end{tabular}

One-way ANOVA

$P$ value

0.98

0.07

0.32

${ }^{\mathrm{a}}$ Values were from duplicate tanks sampled at two distinct time points for a total of four replicate samples per treatment $(n=4)$. Data were subjected to one-way ANOVA, and if significant $(P<0.05)$ differences were detected, means were compared using Tukey-HSD test. Diet ADC of nutrient $=(1-$ $\left[\right.$ yttirum $\left._{\text {diet }} / \mathrm{yttrium}_{\text {feces }} \times \mathrm{Nutr}_{\text {feces } /} \mathrm{Nutr}_{\text {diet }}\right] \times 100 .{ }^{\mathrm{b}}$ Pooled standard error.

of yeast that is used during dry grind ethanol production in the fermentation process, which is further increased when carbohydrates are filtered, concentrating the protein [10]. Yeast is recognized to contain appreciable levels of immunostimulants (e.g., $\beta$-glucans and nucleotides) that can positively impact the health of the organism, although this can vary considerably between DDGS and HP-DDGS production systems [47-49]. Additionally, traditional DDGS and HP-DDGS ingredients possess antioxidant chemicals, particularly ferulic acid, tocopherols, and xanthophylls, potentially increasing immune capabilities of various organisms [50]. Despite some reported immunoenhancements with either form of DDGS ingredient supplementation, various other publications and the present study are inconclusive on positive and/or negative effects of dietary HP-DDGS on immune capacity of fish.

Apparent digestibility coefficient measurements in the present study determined the HP-DDGS ingredient to be highly digestible by advanced stage Nile tilapia. Protein ADC for the test ingredient $(83.1 \%)$ was similar to values reported in the literature for traditional DDGS (ranging from 87.0 to $89.2 \%$ ) [51-53]. Interestingly, ProCap HPDDGS resulted in higher organic matter and similar energy ADC values ( 82.8 and 74.8 , respectively) than reported by Tran-Ngoc et al. (50.7 and 78.1\%, respectively) (2019). Compared to traditional DDGS, the ProCap ingredient is composed of less nonstarch polysaccharides (NSP) potentially resulting in higher ADC values as NSP are less readily digested by monogastric animals including fish, thus lowering energy efficiency [51]. Coupled with a reduction in NDF compared to traditional DDGS [16], the composition of total carbohydrates in the HP-DDGS ingredient offers a credible explanation for higher ADC values for energy and organic matter. These observations are in accordance with the present study's hypothesis.

It is worth mentioning the authors discovered the lipid composition of the ProCap Gold HP-DDGS ingredient limited greater inclusion in a practical diet for Nile tilapia. Although it appears feasible, inclusion rates over $375 \mathrm{~g}$ of $\mathrm{CP} \mathrm{kg}{ }^{-1}$ led to increased dietary lipid values above industry standards. Nonetheless, the use of ProCap HP-DDGS as the primary protein feedstuff in low-fishmeal diets is supported by the current study. 
TABle 8: Apparent digestibility coefficients ${ }^{\mathrm{a}}$ (ADCs) of the ProCap ingredient for juvenile Nile tilapia (mean \pm Std Dev).

\begin{tabular}{lc}
\hline & ProCap \\
\hline Crude protein & $83.1 \pm 10.9$ \\
Crude fat & $72.5 \pm 2.70$ \\
Energy & $82.8 \pm 22.2$ \\
Organic matter & $74.8 \pm 25.8$ \\
His & $93.7 \pm 18.4$ \\
Ser & $91.7 \pm 20.3$ \\
Arg & $92.9 \pm 19.8$ \\
Gly & $93.1 \pm 16.4$ \\
Asp & $92.5 \pm 23.1$ \\
Glu & $95.6 \pm 12.6$ \\
Thr & $85.0 \pm 34.0$ \\
Ala & $94.3 \pm 15.6$ \\
Pro & $94.8 \pm 12.4$ \\
Cys & $98.3 \pm 9.70$ \\
Lys & $89.1 \pm 34.4$ \\
Tyr & $91.9 \pm 16.2$ \\
Met & $89.0 \pm 19.7$ \\
Val & $92.1 \pm 19.8$ \\
Ile & $93.2 \pm 20.4$ \\
Peu & $93.6 \pm 14.6$ \\
\hline Phe & $93.0 \pm 17.8$ \\
\hline
\end{tabular}

${ }^{a}$ Values represent means of quadruplicate samples. Ingredient ADC of nutrient $=\left(\mathrm{ADC}_{\text {exp. diet }}+\left[\left(\mathrm{ADC}_{\text {exp. diet }}-\mathrm{ADC}_{\text {reference diet }}\right) \times(0.75 \times\right.\right.$ Nutrient Comp. $\left.\%_{\text {ref. diet }}\right) /\left(0.25 \times\right.$ Nutrient Comp. $\left.\left.\%_{\text {exp. ingredient }}\right)\right] \times 100$.

In conclusion, soybean meal and fishmeal supplementation with ProCap HP-DDGS up to $375 \mathrm{~g} \mathrm{CP} \mathrm{kg}^{-1}$ without lysine supplementation had no apparent negative effects on growth performance, immune responses, whole-body proximate composition, or condition indices of juvenile Nile tilapia. Additionally, ProCap HP-DDGS had a higher gross energy ADC value than traditional DDGS as reported in previous studies. Thus, inclusion of ProCap HP-DDGS up to $375 \mathrm{~g} \mathrm{CP} \mathrm{kg}^{-1}$ in the diets of juvenile Nile tilapia is supported in the current study.

\section{Data Availability}

The data that supports the findings of the present study are available upon request to the corresponding author.

\section{Conflicts of Interest}

The authors declare that there is no conflict of interest.

\section{Acknowledgments}

This study was performed at the Texas A\&M University Aquacultural Research and Teaching Facility (College Sta- tion, TX, USA) and was funded by Marquis Energy LLC (Hennepin, IL, USA). Blaine Suehs is a Masters student in the Department of Wildlife and Fisheries Sciences and funded through Texas A\&M Agrilife Research. The authors would like to thank the graduate students of the Texas A\&M Fish Nutrition Laboratory for assistance in sampling and experimental procedures, as well as Mr. Brian Ray for logistical assistance.

\section{References}

[1] J. Alder, B. Campbell, V. Karpouzi, K. Kaschner, and D. Pauly, "Forage fish: from ecosystems to markets," Annual Review of Environment and Resources, vol. 33, 2008.

[2] C. Béné, M. Barange, R. Subasinghe et al., "Feeding 9 billion by 2050-putting fish back on the menu," Food Security, vol. 7, pp. 261-274, 2015.

[3] FAO, State of World Fisheries and Aquaculture 2020, Food \& Agriculture Organization, 2020.

[4] A. G. Tacon and M. Metian, "Feed matters: satisfying the feed demand of aquaculture," Reviews in Fisheries Science \& Aquaculture, vol. 23, no. 1, pp. 1-10, 2015.

[5] R. L. Naylor, R. W. Hardy, D. P. Bureau et al., "Feeding aquaculture in an era of finite resources," Proceedings of the National Academy of Sciences, vol. 106, no. 36, pp. 1510315110, 2009.

[6] D. M. Gatlin III, F. T. Barrows, P. Brown et al., "Expanding the utilization of sustainable plant products in aquafeeds: a review," Aquaculture Research, vol. 38, no. 6, pp. 551-579, 2007.

[7] R. L. Lyman and S. Lepkovsky, "The effect of raw soybean meal and trypsin inhibitor diets on pancreatic enzyme secretion in the rat," The Journal of Nutrition, vol. 62, pp. 269-284, 1957.

[8] W. J. Dorsa, H. R. Robinette, E. H. Robinson, and W. Poe, "Effects of dietary cottonseed meal and gossypol on growth of young channel catfish," Transactions of the American Fisheries Society, vol. 111, no. 5, pp. 651-655, 1982.

[9] J. Shurson, DDGS User's Handbook, U.S. Grains Council, Washington, DC, USA, 2018.

[10] R. Bothast and M. Schlicher, "Biotechnological processes for conversion of corn into ethanol," Applied Microbiology and Biotechnology, vol. 67, no. 1, pp. 19-25, 2005.

[11] N. Chevanan, K. A. Rosentrater, and K. Muthukumarappan, "Effect of DDGS, moisture content, and screw speed on physical properties of extrudates in single-screw extrusion," Cereal Chemistry, vol. 85, pp. 132-139, 2008.

[12] P. Fallahi, K. A. Rosentrater, K. Muthukumarappan, and M. Tulbek, "Effects of steam, moisture, and screw speed on physical properties of DDGS-based extrudates," Cereal Chemistry, vol. 90, pp. 186-197, 2013.

[13] K. Mjoun and K. A. Rosentrater, "Co-products of the United States biofuels industry as alternative feed ingredients for aquaculture," Agriculture and Biosystems Engineering, 2012.

[14] X. Li, R. Rezaei, P. Li, and G. Wu, "Composition of amino acids in feed ingredients for animal diets," Amino Acids, vol. 40, pp. 1159-1168, 2011.

[15] NRC, Nutrient Requirements of Fish and Shrimp, National Academies Press, 2011.

[16] J. Han and K. Liu, "Changes in composition and amino acid profile during dry grind ethanol processing from corn and estimation of yeast contribution toward DDGS proteins," Journal 
of Agricultural and Food Chemistry, vol. 58, pp. 3430-3437, 2010.

[17] B. W. Allam, H. S. Khalil, A. T. Mansour, T. M. Srour, E. A. Omar, and A. A. M. Nour, "Impact of substitution of fish meal by high protein distillers dried grains on growth performance, plasma protein and economic benefit of striped catfish (Pangasianodon hypophthalmus)," Aquaculture, vol. 517, article 734792, 2020.

[18] Y. Rho, C. Zhu, E. Kiarie, and C. M. de Lange, "Standardized ileal digestible amino acids and digestible energy contents in high-protein distiller's dried grains with solubles fed to growing pigs," Journal of Animal Science, vol. 95, no. 8, pp. 35913597, 2017.

[19] C. Lim, M. Yildirim-Aksoy, and P. H. Klesius, "Growth Response and Resistance toEdwardsiella ictaluriof Channel Catfish,Ictalurus punctatus, Fed Diets Containing Distiller's Dried Grains with Solubles," Journal of the World Aquaculture Society, vol. 40, no. 2, pp. 182-193, 2009.

[20] Y. Kim, N. S. Mosier, R. Hendrickson et al., "Composition of corn dry-grind ethanol by-products: DDGS, wet cake, and thin stillage," Bioresource Technology, vol. 99, pp. 5165-5176, 2008.

[21] G. Wu, "Functional amino acids in nutrition and health," Amino Acids, vol. 45, pp. 407-411, 2013.

[22] J. Shurson, "Maize dried distillers grains with solubles (DDGS)-a new alternative ingredient in aquafeeds," World Aquaculture, vol. 43, pp. 54-58, 2012.

[23] F. Y. Yamamoto, F. J. Sutili, M. Hume, and D. M. Gatlin III, "The effect of $\beta$-1,3-glucan derived fromEuglena gracilis(Algamune $^{\mathrm{TM}}$ ) on the innate immunological responses of Nile tilapia (Oreochromis niloticusL.)," Journal of Fish Diseases, vol. 41, no. 10, pp. 1579-1588, 2018.

[24] Association of Official Analytical Chemists (AOAC), Official Methods of Analysis of AOAC International, AOAC international, 2005.

[25] W. Rossi Jr., J. R. Tomasso, and D. M. Gatlin III, “Performance of cage-raised, overwintered hybrid striped bass fed fish Mealor soybean-based diets," North American Journal of Aquaculture, vol. 77, no. 2, pp. 178-185, 2015.

[26] S. Castillo, S. Halligan, and D. M. Gatlin III, "Growth responses of juvenile red drum Sciaenops ocellatus to dietary phenylalanine and tyrosine can be used to calculate the total aromatic amino acid requirement," The Journal of Nutrition, vol. 145, pp. 2341-2346, 2015.

[27] A. K. Siwicki, D. P. Anderson, and G. L. Rumsey, "Dietary intake of immunostimulants by rainbow trout affects nonspecific immunity and protection against furunculosis," Veterinary Immunology and Immunopathology, vol. 41, pp. 125139, 1994.

[28] F. Y. Yamamoto, S. Castillo, C. R. de Cruz, K. Chen, M. E. Hume, and D. M. Gatlin III, "Synergistic effects of the $\beta-1,3$ glucan paramylon and vitamin $\mathrm{C}$ on immunological responses of hybrid striped bass (Morone chrysops $\times$ M. saxatilis) were pronounced in vitro but more moderate in vivo," Aquaculture, vol. 526, article 735394, 2020.

[29] A. E. Ellis, "Serum antiproteases in fish," Techniques in Fish Immunology, pp. 95-99, 1990.

[30] I. E. Belal, "A review of some fish nutrition methodologies," Bioresource Technology, vol. 96, no. 4, pp. 395-402, 2005.

[31] A. K. Amirkolaie, S. A. el-Shafai, E. H. Eding, J. W. Schrama, and J. A. Verreth, "Comparison of faecal collection method with high- and low-quality diets regarding digestibility and faeces characteristics measurements in Nile tilapia," Aquaculture Research, vol. 36, no. 6, pp. 578-585, 2005.

[32] S. D. Coyle, G. J. Mengel, J. H. Tidwell, and C. D. Webster, "Evaluation of growth, feed utilization, and economics of hybrid tilapia, Oreochromis niloticus $x$ Oreochromis aureus, fed diets containing different protein sources in combination with distillers dried grains with solubles," Aquaculture Research, vol. 35, no. 4, pp. 365-370, 2004.

[33] S. S. Herath, Y. Haga, and S. Satoh, "Potential use of corn coproducts in fishmeal-free diets for juvenile Nile tilapia Oreochromis niloticus," Fisheries Science, vol. 82, pp. 811-818, 2016.

[34] B. Gause and J. Trushenski, "Production performance and stress tolerance of sunshine bass raised on reduced fish meal feeds containing ethanol yeast," North American Journal of Aquaculture, vol. 73, pp. 168-175, 2011.

[35] M. Øverland, Å. Krogdahl, G. Shurson, A. Skrede, and V. Denstadli, "Evaluation of distiller's dried grains with solubles (DDGS) and high protein distiller's dried grains (HPDDG) in diets for rainbow trout (Oncorhynchus mykiss)," Aquaculture, vol. 416-417, pp. 201-208, 2013.

[36] A. M.-S. Goda, S. R. Ahmed, H. M. Nazmi et al., “Assessment of a high protein distillers dried grain (HP-DDG) augmented with phytase in diets for European sea bass, Dicentrarchus labrax fingerlings on growth performance, haematological status, immune response and related gut and liver histology," Aquaculture, vol. 529, article 735617, 2020.

[37] S. S. Herath, Y. Haga, and S. Satoh, "Effects of long-term feeding of corn co-product-based diets on growth, fillet color, and fatty acid and amino acid composition of Nile tilapia, Oreochromis niloticus," Aquaculture, vol. 464, pp. 205212, 2016.

[38] R. Wilson and C. Cowey, "Amino acid composition of whole body tissue of rainbow trout and Atlantic salmon," Aquaculture, vol. 48, no. 3-4, pp. 373-376, 1985.

[39] G. Wu, Amino Acids: Biochemistry and Nutrition, CRC Press, 2013.

[40] E. Li, C. Lim, C. Cai, and P. H. Klesius, "Growth response and resistance to Streptococcus iniae of Nile tilapia, Oreochromis niloticus, fed diets containing different levels of wheat distiller's dried grains with solubles with or without lysine supplementation," Animal Feed Science and Technology, vol. 170, pp. 246-255, 2011.

[41] C. Lim, J. C. Garcia, M. Yildirim-Aksoy, P. H. Klesius, C. A. Shoemaker, and J. J. Evans, "Growth response and resistance to Streptococcus iniae of Nile tilapia, Oreochromis niloticus, fed diets containing Distiller?s dried grains with solubles," Journal of the World Aquaculture Society, vol. 38, no. 2, pp. 231-237, 2007.

[42] P. Zhou, W. Zhang, D. A. Davis, and C. Lim, "Growth response and feed utilization of juvenile hybrid catfish fed diets containing distiller's dried grains with solubles to replace a combination of soybean meal and corn meal," North American Journal of Aquaculture, vol. 72, pp. 298-303, 2010.

[43] G. J. Lieschke and N. S. Trede, "Fish immunology," Current Biology, vol. 19, pp. R678-R682, 2009.

[44] R. A. Shelby, C. Lim, M. Yildrim-Aksoy, and P. H. Klesius, "Effect of distillers dried grains with solubles-incorporated diets on growth, immune function and disease resistance in Nile tilapia (Oreochromis niloticusL.)," Aquaculture Research, vol. 39, no. 12, pp. 1351-1353, 2008. 
[45] T. W. Schaeffer, M. L. Brown, and K. A. Rosentrater, "Growth and stress resistance of advanced sized Nile tilapia fed diets containing fuel-based DDGS and yeast," Journal of Applied Aquaculture, vol. 24, pp. 210-220, 2012.

[46] A. A. S. Goda, T. M. Srour, E. Omar et al., "Appraisal of a high protein distiller's dried grain (DDG) in diets for European sea bass,Dicentrarchus labraxfingerlings on growth performance, haematological status and related gut histology," Aquaculture Nutrition, vol. 25, no. 4, pp. 808-816, 2019.

[47] M. Alizadeh, J. Rodriguez-Lecompte, A. Rogiewicz, R. Patterson, and B. Slominski, "Effect of yeast-derived products and distillers dried grains with solubles (DDGS) on growth performance, gut morphology, and gene expression of pattern recognition receptors and cytokines in broiler chickens," Poultry Science, vol. 95, no. 3, pp. 507-517, 2016.

[48] P. N. Lipke and R. Ovalle, "Cell wall architecture in yeast: new structure and new challenges," Journal of Bacteriology, vol. 180, pp. 3735-3740, 1998.

[49] F. Y. Yamamoto, F. Yin, W. Rossi Jr., M. Hume, and D. M. Gatlin III, " $\beta-1,3$ glucan derived from Euglena gracilis and Algamune $^{\mathrm{TM}}$ enhances innate immune responses of red drum (Sciaenops ocellatus L.)," Fish \& Shellfish Immunology, vol. 77, pp. 273-279, 2018.

[50] E.-C. Shin, G. C. Shurson, and D. D. Gallaher, "Antioxidant capacity and phytochemical content of 16 sources of corn distillers dried grains with solubles (DDGS)," Animal Nutrition, vol. 4, pp. 435-441, 2018.

[51] M. N. Haidar, M. Petie, L. T. Heinsbroek, J. A. Verreth, and J. W. Schrama, "The effect of type of carbohydrate (starch vs. nonstarch polysaccharides) on nutrients digestibility, energy retention and maintenance requirements in Nile tilapia," Aquaculture, vol. 463, pp. 241-247, 2016.

[52] M. Soltan, A. Radwan, and A. Gomaa, "Using distillers dried grains as an alternative protein source in Nile tilapia (Oreochromis niloticus) feeds," Egyptian Journal of Aquatic Biology and Fisheries, vol. 19, pp. 23-33, 2015.

[53] K. T. Tran-Ngoc, M. N. Haidar, A. J. Roem, J. Sendão, J. A. Verreth, and J. W. Schrama, "Effects of feed ingredients on nutrient digestibility, nitrogen/energy balance and morphology changes in the intestine of Nile tilapia (Oreochromis niloticus)," Aquaculture Research, vol. 50, no. 9, pp. 2577-2590, 2019. 